\title{
Effect of Biscuits and Muffins Added with Cornlettes Powder on the Glycemic Responses of Healthy Individuals
}

\author{
Che Anis Jauharah Che Mohd Zin, Sathyasurya Daniel Robert, Wan Rosli Wan Ishak* \\ Nutrition Program, School of Health Sciences, Universiti Sains Malaysia, Kubang Kerian, Malaysia \\ Email: anisjauharah@gmail.com, daniel@usm.my, ${ }^{*}$ rosliishak@gmail.com
}

Received 6 October 2014; revised 2 November 2014; accepted 16 November 2014

Copyright (C) 2014 by authors and Scientific Research Publishing Inc.

This work is licensed under the Creative Commons Attribution International License (CC BY). http://creativecommons.org/licenses/by/4.0/ (c) (i) Open Access

\begin{abstract}
Dietary fibre content is a known factor that can affect the postprandial glycemic responses of a food and meal. Cornlettes vegetable which is rich in dietary fibre has been studied for its potential in lowering the peak glycemic responses of biscuits and muffins. Cornlettes was processed into powder and formulated into four formulations of selected bakery products. The glycemic responses produced by portions of the biscuits and muffins containing $25 \mathrm{~g}$ available carbohydrate were measured in 11 healthy volunteers. The incremental area under curve (AUC) of control biscuits was greater $(81 \pm 11 \mathrm{mmol} \times \mathrm{min} / \mathrm{l})$ than cornlettes powder (CP) added biscuit (63 \pm 12 mmol $\times$ min/l). Likewise, the AUC of control muffins was higher $(88 \pm 13 \mathrm{mmol} \times \mathrm{min} / \mathrm{l})$ than CP-added muffins (74 $\pm 12 \mathrm{mmol} \times \mathrm{min} / \mathrm{l})$. Control biscuits had an intermediate GI value of 61 while CP-added biscuits had a low GI value of 46 . Both control and CP-added muffins recorded intermediate GI values (58 and 57, respectively). It is concluded that CP can be incorporated in selected bakery products as a potential ingredient to help lower the peak rise of postprandial glycemic responses.
\end{abstract}

\section{Keywords}

Biscuit, Cornlettes, Glycemic Index, Muffin

\section{Introduction}

In the twenty-first-century, the prevalence of non-communicable diseases (NCD) such as diabetes, cardiovascular diseases and obesity is rapidly rising in developed and developing nations. The WHO [1] reported that nearly

\footnotetext{
${ }^{*}$ Corresponding author.
}

How to cite this paper: Zin, C.A.J.C.M., Robert, S.D. and Ishak, W.R.W. (2014) Effect of Biscuits and Muffins Added with Cornlettes Powder on the Glycemic Responses of Healthy Individuals. Food and Nutrition Sciences, 5, 2195-2202. 
two thirds (63\%) of all deaths occurring globally in 2008 were due to NCD and the number is anticipated to increase in the years ahead. Postprandial hyperglycemia is a treatable cause towards the burden of chronic diseases [2]. Glucose "spike" following a regular meal has been reported to worsen diabetic condition and threaten health of cardiovascular system [3]. Therefore, dietary modification becomes a crucial measure in preventing further complications and improving patients' quality of life. Meanwhile, among healthy individuals, good dietary practice will be helpful in preventing NCD. Bakery products such as biscuits, muffins, cakes and breads are widely consumed and they are rich in carbohydrate. Dietary carbohydrate has direct and greater influence on postprandial blood glucose than other components of the diet, like protein and fat [4]. Foods high in carbohydrate can be categorized according to the glycemic index (GI) concept which is based on the physiological response (postprandial glycemia) produced by the carbohydrate. The concept was firstly coined by Jenkins et al. [5]. The GI is defined by FAO/WHO [6] as "the incremental area under the blood glucose response curve of a 50 g available carbohydrate portion of a test food expressed as percent of the response to the same amount of carbohydrate from a reference food consumed by the same subject”. It was previously shown that low GI diet was beneficial in reducing risks and complications of various health conditions like diabetes [7], cardiovascular diseases [8] and cancers [9]-[11]. The GI value of food or meals is affected by addition of dietary fibre [12] [13]. Trowell [14] described dietary fibre as "portion of food that is derived from cellular walls of plants which resist hydrolysis by digestive enzymes of human”. It improves glycemic response by reducing rate of glucose absorption in small intestine [15]. Other than wholegrain cereals, fruits and vegetables are widely known as sources of dietary fibre. However, fruits and vegetables consumption is still below recommendation of five servings a day, particularly in low- and middle-income populations [16].

Cornlettes (young Zea mays) is a type of vegetable commonly found in Asian cuisines which has a sweet and succulent taste. It appears yellow in colour and its size is of finger-length. Cornlettes is a unique product of corn since the harvested part is the immature female inflorescence rather than mature plant or ear [17]. It is usually hand-picked prior to fertilization and before or just after the emergence of the corn silk. Nutrients in cornlettes were comparable with other vegetables like cauliflower, cabbage, tomato, eggplant and cucumber [18]. Hooda and Kawatra [19] reported that cornlettes is rich in dietary fibre (27.12 g/100g). Natural dietary fibre in cornlettes may potentially be incorporated into food products as a source of functional ingredient for health promotional purposes. Other than being nutritious, it is also free from pesticides because the cob is tightly protected in its husk [20].

There are limited findings to show the potential of cornlettes in controlling the postprandial blood glucose responses among normal individuals. Therefore, the present study was carried out with aims to develop bakery products incorporated with cornlettes powder (CP) and to compare the postprandial glucose responses produced by biscuits and muffins formulated with CP and without CP. Thus, the ability of cornlettes in lowering the glucose response of selected bakery products can be revealed.

\section{Materials and Methods}

\subsection{Control Foods and Test Foods}

Fresh cornlettes was collected from Pasir Mas, Kelantan, Malaysia. The young cob was manually separated from husk and silk. Then, they were chopped (1 - $2 \mathrm{~cm}$ in length) and dried in oven (Memmert GmbH \& Co. KG, Germany) at $55^{\circ} \mathrm{C}$ for 2 days. The dried samples were later ground using electric blender (National MX-895M, Malaysia) to obtain fine cornlettes powder $(250 \mu \mathrm{m})$. Cornlettes powder (CP) was stored in screw cap bottle (Scott Duran, Germany) at $4^{\circ} \mathrm{C}$ for further analyses.

Test biscuits were prepared by adding $10 \mathrm{~g}$ of CP to $90 \mathrm{~g}$ of wheat flour, $21 \mathrm{~g}$ corn flour, $46 \mathrm{~g}$ margarine, $37 \mathrm{~g}$ sucrose, $31 \mathrm{~g}$ egg and $1 \mathrm{~g}$ baking powder. As for the control biscuits CP was not added. Initially, fat and sucrose was combined using hand mixer (Khind HM200, Malaysia) at speed 5. Next, egg was added and mixing was continued for 2 minutes. Wheat flour, corn flour, baking powder and CP were then added into the creaming mixture. They were mixed to obtain uniform dough. The dough was rolled out to a height of 5 mm and cut into square shape $2.5 \times 2.5 \mathrm{~cm}$ using biscuit mould. The biscuits were then baked at $160^{\circ} \mathrm{C}$ in oven (Zanussi ZCG841W, England) for $20 \pm 3 \mathrm{~min}$.

For the test muffins, $30 \mathrm{~g}$ of CP was added with $70 \mathrm{~g}$ of wheat flour, $5 \mathrm{~g}$ baking powder, $81 \mathrm{~g}$ sucrose, egg, $56 \mathrm{~g}$ milk and $57 \mathrm{ml}$ sunflower oil. The egg was beaten for $2 \mathrm{~min}$, followed by addition of milk and oil. In a separate bowl, all dry ingredients were thoroughly mixed. Then, the dry and wet ingredients were combined to obtain 
homogenous muffin batter. Seventy grams of batter were filled in each $45 \mathrm{~mm}$ diameter paper muffin cup. The muffins were baked at $215^{\circ} \mathrm{C}$ in oven (Zanussi ZCG841W, England) for $15 \pm 3 \mathrm{~min}$. The control muffins were prepared without adding the $\mathrm{CP}$.

\subsection{Nutritional Compositions Analyses}

Analyses were carried out based on AOAC [21]. Content of protein was determined by Kjeldahl method with a conversion factor of 6.25 and crude fat by Soxhlet method employing extraction with petroleum ether. Total carbohydrate content was calculated by difference [22]. Total dietary fibre (TDF) was analysed according to enzymatic gravimetric method (AOAC 985.29). Available carbohydrate was calculated by total carbohydrate minus TDF.

\subsection{Sensory Evaluation}

Sixty panelists consisting of students and staffs of School of Health Sciences took part in the sensory evaluation to rate the biscuits and muffins. Ratings were given according to their preferences based on seven-point hedonic scale by Aminah et al. [23].

\subsection{Evaluation of Postprandial Blood Glucose Responses}

Non-diabetic, healthy volunteers ( $\mathrm{n}=11,5$ men, 6 women) with a mean \pm SD age of $29 \pm 5$ years old participated in the study. Their mean body mass indices were normal $\left(23 \pm 2 \mathrm{~kg} / \mathrm{m}^{2}\right)$. The fasting plasma glucose of the subjects was $5.3 \pm 0.7 \mathrm{mmol} / \mathrm{l}$. For participation, all volunteers were given written informed consent. Ethical approval for the study was acquired from the Research Ethics Committee (Human) of Universiti Sains Malaysia (USMKK/PPP/JEPeM (227.3) [3]).

The test foods consisted essentially of either one of the biscuits, muffins or reference glucose drink (25 g dextrose monohydrate in $250 \mathrm{ml}$ drinking water). All foods contained $25 \mathrm{~g}$ available carbohydrate. In addition, standard drink of water $(250 \mathrm{ml})$ was served with each test food. Table 1 shows the macronutrient composition of test foods.

Individual was tested with the reference food, glucose (Glucolin, Reckitt Beckinser, Malaysia) for 3 times while the test foods were tested once. Seven different test foods were provided at breakfast after an overnight fast on separate mornings 1 week apart. Test meals were eaten over 15 min. Zero time was set as the time eating began. Finger-prick capillary blood samples were obtained using lancing device (Accu-Chek Multiclix, USA). On each occasion, after fasting blood sample was collected $(4 \mu \mathrm{l})$ the subjects ate the control or test food and had further blood samples taken at 15, 30, 45, 60, 90, and 120 min after starting to eat. Collected capillary blood samples were then analyzed for glucose with Hemo Cue Glucose 201 RT (Ängelholm, Sweden) that uses modified dehydrogenase method. The instrument automatically transformed and showed the results in plasma equivalent reading. Thus, results of the HemoCue Glucose 201 RT will be referred to as plasma glucose, even though whole blood was analyzed. The GI was calculated from the 2-hour incremental glucose area using glucose drink as reference $(\mathrm{GI}=100)$. Incremental area under the curve (AUC) was calculated geometrically and ignoring area under the baseline fasting level [24].

\subsection{Statistical Analyses}

Statistical analyses were performed using Microsoft Excel Spreadsheet (Excel 2007), IBM Statistics Package for

Table 1. Composition of test meals.

\begin{tabular}{ccccccc}
\hline & Portion size (g) & Energy (kcal) & Protein (g) & Fat (g) & Dietary fibre (g) & Available CHO (g) \\
\hline Control biscuits & 37 & 127 & 1.7 & 5.4 & 0.2 & 25 \\
CP-added biscuits & 39 & 128 & 1.9 & 5.3 & 0.8 & 25 \\
Control muffins & 49 & 102 & 1.7 & 3.4 & 0.6 & 25 \\
CP-added muffins & 63 & 106 & 2.0 & 3.0 & 2.0 & 25 \\
\hline
\end{tabular}


Social Sciences (IBM SPSS Statistics 19) and GraphPad Prism (GraphPad Software Version 5). Results for nutritional compositions were presented as mean values of three replicates. Sensory acceptance scores of biscuits and muffins were analyzed separately using independent $t$-test and presented as mean \pm SD. The GI values were expressed in mean \pm SEM. The AUC of repeated reference glucose test were calculated for mean, SEM and coefficient of variation $(\mathrm{CV}=100 \times \mathrm{SD} /$ mean $)$ of each subject.

The AUC and GI values of all subjects obtained from four test sessions of biscuits and muffins testing were subjected to repeated measures ANOVA. A value of $p<0.05$ was considered significant. Results are expressed as mean \pm SEM.

\section{Results and Discussion}

Sensory evaluation by 60 panelists revealed that CP-added biscuits were comparable to controls for most attributes. The CP-added muffins received significantly better score than control muffins for majority of the attributes tested. Mean scores for each sensory attributes of biscuits and muffins were presented in Table 2.

The test meals were well tolerated and the seven test sessions were successfully completed by all subjects. GI is often measured using $50 \mathrm{~g}$ of available carbohydrate portions of food. However, $25 \mathrm{~g}$ available carbohydrate portion is allowed in GI methodology [25] as to avoid unrealistically large serving size which can create inconvenience in subjects to finish the food in limited time. Hence in the present study we served our subjects with food portions containing $25 \mathrm{~g}$ of available carbohydrate. The CV of the AUC of three times repeated glucose tests was $19.0 \% \pm 9.6 \%$. Comparisons of the mean blood glucose response of the control foods and the CP added biscuits and muffins are shown in Figure 1 and Figure 2, respectively.

Our study demonstrated that addition of CP in biscuits and muffins had reduced the peak postprandial glycemic responses of healthy individuals. We noted that at $30 \mathrm{~min}$ the mean blood glucose response of CP-added biscuits $[6.6 \mathrm{mmol} / 1,95 \% \mathrm{CI}(6.0,7.2)]$ was significantly lower than the mean blood glucose response of control biscuits $[7.3 \mathrm{mmol} / \mathrm{l}, 95 \% \mathrm{CI}(6.7,7.9)]$. Similarly, the peak plasma glucose of CP-added muffins $[6.2 \mathrm{mmol} / \mathrm{l}$, $95 \%$ CI $(5.5,6.8)]$ was significantly lower than the peak plasma glucose of control muffins [6.9 mmol/l, 95\% CI $(6.3,7.5)]$. In accordance with the study done by Jenkins et al. [26], a very potent and palatable soluble fibre, known as viscous fibre blend, when added to starchy snacks, particularly biscuits, was able to reduce the glycemic response to a similar extent in both healthy individuals and patients with diabetes mellitus. Most vegetables are known to be rich in dietary fibre. It was reported that CP had 38.7\% dietary fibre [27], which may play a crucial role in lowering the peak glycemic responses when incorporated in biscuits and muffins. Presence of dietary fibre can delay gastric emptying and retards digestion and absorption rate of available carbohydrates in small intestines [15] [28]. Conclusions reached in various studies on types of dietary fibre that affect blood glucose were contradicted. Wolever [29] demonstrated that cellulose and uronic acid component of insoluble fibre contents had closer relationship with GI than soluble fibre. On the contrary, other finding showed that soluble fibre had more effect on glycemia [30]. Recently, Weickert and Pfeiffer [31] reported that soluble dietary fibre can slow gastric emptying and macronutrient absorption from the gut while insoluble fibre can increase insulin sensitivity whereby both will control elevation of postprandial glycemic response.

Table 2. Sensory acceptance of biscuits and muffins.

\begin{tabular}{|c|c|c|c|c|c|}
\hline \multirow{2}{*}{ Test foods } & \multicolumn{5}{|c|}{ Mean scores for each sensory attribute tested (maximum score of 7) } \\
\hline & Appearance & Crispiness & Aroma & Flavour & $\begin{array}{c}\text { Overall } \\
\text { acceptance }\end{array}$ \\
\hline Control biscuits & $4.97 \pm 1.44^{\mathrm{a}}$ & $5.32 \pm 1.26^{\mathrm{a}}$ & $4.77 \pm 1.47^{\mathrm{a}}$ & $4.92 \pm 1.34^{\mathrm{a}}$ & $4.97 \pm 1.30^{\mathrm{a}}$ \\
\hline \multirow[t]{2}{*}{ CP-added biscuits } & $4.97 \pm 1.13^{\mathrm{a}}$ & $5.33 \pm 1.02^{\mathrm{a}}$ & $5.00 \pm 1.22^{\mathrm{a}}$ & $5.28 \pm 1.18^{\mathrm{a}}$ & $5.27 \pm 1.02^{a}$ \\
\hline & Appearance & Texture & Taste & Flavour & $\begin{array}{c}\text { Overall } \\
\text { acceptance }\end{array}$ \\
\hline Control muffins & $4.27 \pm 1.73^{\mathrm{b}}$ & $3.82 \pm 1.74^{\mathrm{c}}$ & $4.10 \pm 1.46^{\mathrm{c}}$ & $4.13 \pm 1.44^{\mathrm{c}}$ & $4.17 \pm 1.38^{\circ}$ \\
\hline CP-added muffins & $4.68 \pm 1.46^{\mathrm{b}}$ & $4.80 \pm 1.41^{\mathrm{b}}$ & $4.67 \pm 1.60^{\mathrm{b}}$ & $4.83 \pm 1.64^{\mathrm{b}}$ & $4.80 \pm 1.42^{\mathrm{b}}$ \\
\hline
\end{tabular}

Values are mean \pm standard deviations. Mean in the same column with different letter differ significantly $(\mathrm{p}<0.05)$. 




Figure 1. Mean blood glucose responses to control biscuits compared with CP-added biscuits.

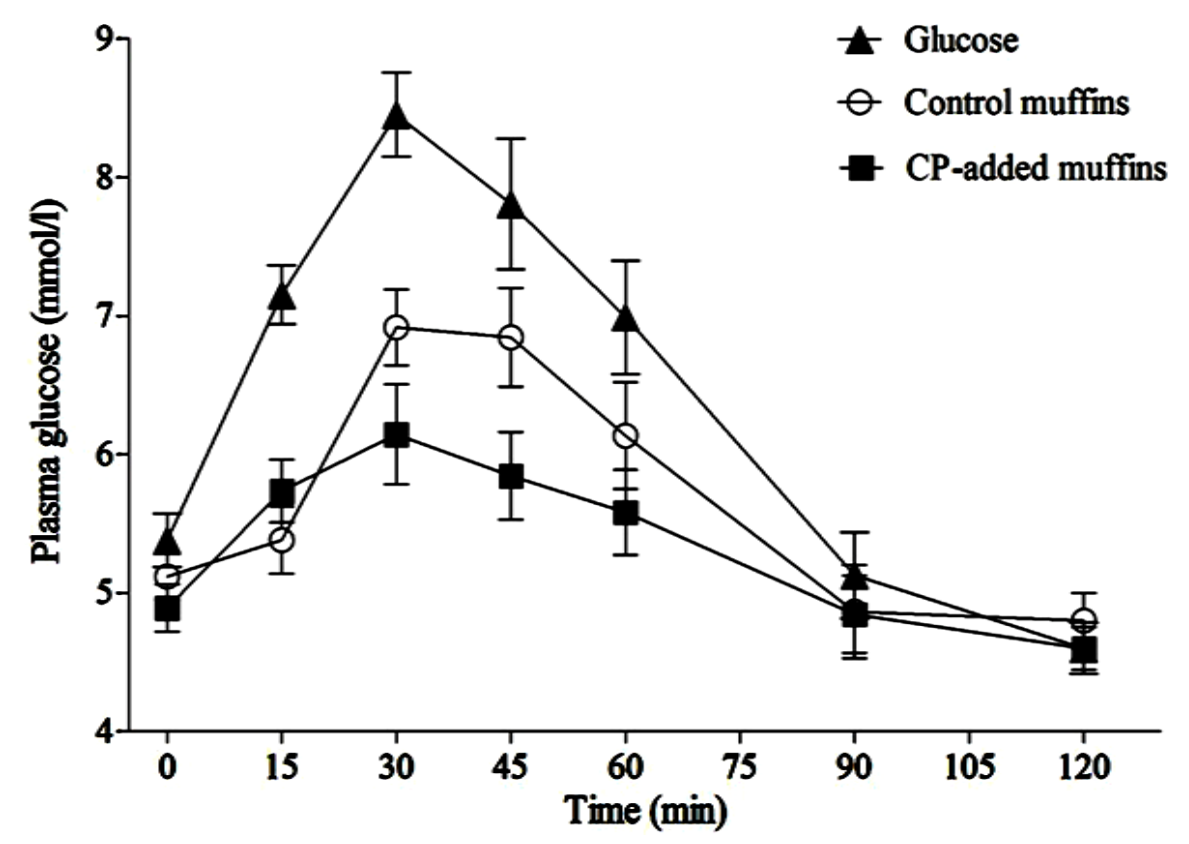

Figure 2. Mean blood glucose responses to control muffins compared with CP-added muffins.

Type of sugar can also affect the postprandial glucose responses [32]. Previous work reported that CP contains 5.3\% fructose and negligible amount of glucose [33]. Glucose and fructose are structurally different although their molecular formulas are identical. Fructose is metabolized primarily in the liver and absorbed in the jejunum, thus producing less glucogenic effect compared to sucrose and glucose [34]. Crapo et al. [35] demonstrated that glycemic responses produced by fructose was smaller than dextrose and sucrose. Study by Moore et al. [36] reported that low dose fructose administration in normal adults plays an important catalytic role to increase hepatic glucose uptake which subsequently lower the glycemic response and improves glucose tolerance. Additionally, Heacock et al. [37] found that administration of fructose prior to high GI diet can substantially lower the postprandial glycemic response. 
The presence of fat may have also influence the postprandial glucose responses in biscuits and muffins. Fat reduces glycemic response by slowing gastric emptying, stimulating insulin release and accelerating secretions of incretin hormones such as glucagon-like peptide-1 (GLP-1) and glucose-dependent insulinotropic polypeptide (GIP) [38]. In addition, according to Henry et al. [39], different degree of fat saturation can equally lower glycemic response. Since different types of fat have same influence on GI, unsaturated fat is likely more favourable than saturated fat for its benefit on blood lipid profile.

Although addition of CP can significantly lower the peak postprandial blood glucose responses, the difference between mean AUC of control biscuits and CP-added biscuits was not statistically significant $(p>0.95)$. The glycemic responses of the control biscuits was significantly less than that of reference glucose $(p=0.04)$. Likewise, the glycemic responses of the CP-added biscuits was also significantly less than that of glucose $(p=0.01)$. The control biscuits had an intermediate GI value (61 \pm 13 ) while the CP-added biscuits had a low GI value (46 \pm 11 ).

On the other hand, there was also no significant difference between AUC of control muffins and CP-added muffins ( $p>0.95)$. However, the AUC after control muffins was significantly less than after glucose $(p=0.003)$. The AUC after CP-added muffins was also significantly less than after glucose $(\mathrm{p}=0.03)$. Both control muffins and CP-added muffins had an intermediate GI values (58 \pm 6 and $57 \pm 9$, respectively) (Table 3).

Factors such as different food matrices, percentage of ingredients in the formulations as well as composition of nutrients in biscuits and muffins could be the contributing factors that affect blood glucose responses. In earlier studies among pasta products, spaghetti which was higher in density elicited greater glucose response than macaroni [40]. Higher glucose response of muffins than biscuits could be due to varying density of muffins and biscuits. Besides that, low moisture content in biscuits may obstruct starch hydration during baking (known as gelatinization process in the product) and reduce the availability to carbohydrate digestive enzyme, amylase [41]. Therefore, digestion of biscuit will be at a slower rate, leading to lower glucose response.

According to the International Tables of Glycemic Index and Load the GI value of biscuits is between 68 to 72 and that of muffins is between 44 to 60 [42]. In the present study, it was found that the GI value of CP added biscuit was low $(\mathrm{GI}=46)$ and that of the muffins was intermediate. Hence CP added biscuits and muffins may be useful in providing health benefits for suitable consumers. Moreover diet education regarding the selection of healthy carbohydrate foods and practical application of the GI concept is vital for the well-being of the general population.

\section{Conclusion and Study Limitations}

In conclusion, this study showed that the novel food ingredient cornlettes powder can be incorporated in selected bakery products to help reduce the postprandial blood glucose response and to develop a food product with a low GI value. However, this study did not specifically determine the active phytonutrient components in the cornlettes that are responsible for the effect on peak postprandial glucose of biscuits and muffins. Therefore, further researches are needed to identify the phytonutrients that may have involved and their stability, and more food products can be developed by adding CP.

\section{Acknowledgements}

This study was supported by Universiti Sains Malaysia (1001/PPSK/813057). We thank the staffs of Nutrition

Table 3. Glucose responses and GI of biscuits and muffins with and without cornlettes powder.

\begin{tabular}{ccc}
\hline Test food & AUC mmol $\times$ min/l & GI \\
\hline Control biscuits & $81 \pm 11^{\mathrm{b}}$ & $61 \pm 13^{\mathrm{b}}$ \\
CP-added biscuits & $63 \pm 12^{\mathrm{b}}$ & $46 \pm 11^{\mathrm{b}}$ \\
Control muffins & $88 \pm 13^{\mathrm{b}}$ & $58 \pm 6^{\mathrm{b}}$ \\
CP-added muffins & $74 \pm 12^{\mathrm{b}}$ & $59^{\mathrm{b}}$ \\
Glucose & $154 \pm 17^{\mathrm{a}}$ & $100^{\mathrm{a}}$ \\
\hline
\end{tabular}

Data are means and SEM. Different superscript letters within same column indicate significant differences $(p<0.05)$ between the foods. 
Lab, Dietetic Lab and Food Preparation Lab, School of Health Sciences for their technical support.

\section{References}

[1] WHO (2011) Global Status Report on Noncommunicable Diseases 2010. World Health Organization, Geneva.

[2] Gerich, J.E. (2003) Clinical Significance, Pathogenesis, and Management of Postprandial Hyperglycemia. Archives of Internal Medicine, 163, 1306-1316. http://dx.doi.org/10.1001/archinte.163.11.1306

[3] Ceriello, A. (2005) Postprandial Hyperglycemia and Diabetes Complications Is It Time to Treat? Diabetes, 54, 1-7. http://dx.doi.org/10.2337/diabetes.54.1.1

[4] Sheard, N.F., Clark, N.G., Brand-Miller, J.C., Franz, M.J., Pi-Sunyer, F.X., Mayer-Davis, E., Kulkarni, K. and Geil, P. (2004) Dietary Carbohydrate (Amount and Type) in the Prevention and Management of Diabetes: A Statement by the American Diabetes Association. Diabetes Care, 27, 2266-2271. http://dx.doi.org/10.2337/diacare.27.9.2266

[5] Jenkins, D.J., Wolever, T.M., Taylor, R.H., Barker, H., Fielden, H., Baldwin, J.M., Bowling, A.C., Newman, H.C., Jenkins, A.L. and Goff, D.V. (1981) Glycemic Index of Foods: A Physiological Basis for Carbohydrate Exchange. The American Journal of Clinical Nutrition, 34, 362-366.

[6] FAO/WHO (1998) Carbohydrates in Human Nutrition. FAO, Rome.

[7] Salmeron, J., Ascherio, A., Rimm, E.B., Colditz, G.A., Spiegelman, D., Jenkins, D.J., Stampfer, M.J., Wing, A.L. and Willett, W.C. (1997) Dietary Fiber, Glycemic Load, and Risk of NIDDM in Men. Diabetes Care, 20, 545-550. http://dx.doi.org/10.2337/diacare.20.4.545

[8] Barclay, A.W., Petocz, P., McMillan-Price, J., Flood, V.M., Prvan, T., Mitchell, P. and Brand-Miller, J.C. (2008) Glycemic Index, Glycemic Load, and Chronic Disease Risk-A Meta-Analysis of Observational Studies. The American Journal of Clinical Nutrition, 87, 627-637.

[9] Augustin, L.S.A., Maso, L.D., Vecchia, C.L., Parpinel, M., Negri, E., Vaccarella, S., Kendall, C.W.C., Jenkins, D.J.A. and Franceschi, S. (2001) Dietary Glycemic Index and Glycemic Load, and Breast Cancer Risk: A Case-Control Study. Annals of Oncology, 12, 1533-1538. http://dx.doi.org/10.1023/A:1013176129380

[10] Augustin, L.S.A., Gallus, S., Bosetti, C., Levi, F., Negri, E., Franceschi, S., Dal Maso, L., Jenkins, D.J.A., Kendall, C.W.C. and La Vecchia, C. (2003) Glycemic Index and Glycemic Load in Endometrial Cancer. International Journal of Cancer, 105, 404-407. http://dx.doi.org/10.1002/ijc.11089

[11] Gnagnarella, P., Gandini, S., La Vecchia, C. and Maisonneuve, P. (2008) Glycemic Index, Glycemic Load, and Cancer Risk: A Meta-Analysis. The American Journal of Clinical Nutrition, 87, 1793-1801.

[12] Schulze, M.B., Liu, S., Rimm, E.B., Manson, J.E., Willett, W.C. and Hu, F.B. (2004) Glycemic Index, Glycemic Load, and Dietary Fiber Intake and Incidence of Type 2 Diabetes in Younger and Middle-Aged Women. The American Journal of Clinical Nutrition, 80, 348-356.

[13] Hodge, A.M., English, D.R., O’Dea, K. and Giles, G.G. (2004) Glycemic Index and Dietary Fiber and the Risk of Type 2 Diabetes. Diabetes Care, 27, 2701-2706. http://dx.doi.org/10.2337/diacare.27.11.2701

[14] Trowell, H. (1976) Definition of Dietary Fiber and Hypotheses That It Is a Protective Factor in Certain Diseases. The American Journal of Clinical Nutrition, 29, 417-427.

[15] Cherbut, C., Des Varannes, S.B., Schnee, M., Martine, R., Galmiche, J. and Delort-Laval, J. (1994) Involvement of Small Intestinal Motility in Blood Glucose Response to Dietary Fibre in Man. British Journal of Nutrition, 71, 615-685. http://dx.doi.org/10.1079/BJN19940175

[16] Hall, J.N., Moore, S., Harper, S.B. and Lynch, J.W. (2009) Global Variability in Fruit and Vegetable Consumption. American Journal of Preventive Medicine, 36, 402-409. http://dx.doi.org/10.1016/j.amepre.2009.01.029

[17] Hallauer, A.R. (2001) Specialty Corns. CRC Press, Boca Raton.

[18] Yodpet, C. (1979) Studies on Sweet Corn as Potential Young Cob Corn (Zea mays L.). Ph.D. Thesis, University of Philippines, Quezon City.

[19] Hooda, S. and Kawatra, A. (2013) Nutritional Evaluation of Baby Corn (Zea mays). Nutrition \& Food Science, 43, 6873. http://dx.doi.org/10.1108/00346651311295932

[20] Chutkaew, C. and Paroda, R.S. (1994) Baby Corn Production in Thailand: A Success Story. Asia-Pacific Association of Agricultural Research Innovation Publication, Bangkok.

[21] AOAC (1996) Official Method of Analysis of the Association of Official Analytical Chemists. AOAC International, Arlington.

[22] Southgate, D.A.T. (1991) Determination of Food Carbohydrates. Elsevier Applied Science, London.

[23] Aminah, A. (2000) Panduan Makmal Penilaian Sensori. Penerbit UKM, Bangi. 
[24] Wolever, T., Jenkins, D., Jenkins, A. and Josse, R. (1991) The Glycemic Index: Methodology and Clinical Implications. The American Journal of Clinical Nutrition, 54, 846-854.

[25] Brouns, F., Bjorck, I., Frayn, K., Gibbs, A., Lang, V., Slama, G. and Wolever, T. (2005) Glycaemic Index Methodology. Nutrition Research Reviews, 18, 145-171. http://dx.doi.org/10.1079/NRR2005100

[26] Jenkins, A.L., Jenkins, D.J., Wolever, T.M., Rogovik, A.L., Jovanovski, E., Bozikov, V., Rahelic, D. and Vuksan, V. (2008) Comparable Postprandial Glucose Reductions with Viscous Fiber Blend Enriched Biscuits in Healthy Subjects and Patients with Diabetes Mellitus: Acute Randomized Controlled Clinical Trial. Croatian Medical Journal, 49, $772-$ 782. http://dx.doi.org/10.3325/cmj.2008.49.722

[27] Anis Jauharah, M.Z., Wan Rosli, W.I. and Robert, S.D. (2014) Physicochemical and Sensorial Evaluation of Biscuit and Muffin Incorporated with Young Corn Powder. Sains Malaysiana, 43, 45-52.

[28] Benini, L., Castellani, G., Brighenti, F., Heaton, K.W., Brentegani, M.T., Casiraghi, M.C., Sembenini, C., Pellegrini, N., Fioretta, A. and Minniti, G. (1995) Gastric Emptying of a Solid Meal Is Accelerated by the Removal of Dietary Fibre Naturally Present in Food. Gut, 36, 825-830. http://dx.doi.org/10.1136/gut.36.6.825

[29] Wolever, T. (1990) Relationship between Dietary Fiber Content and Composition in Foods and the Glycemic Index. The American Journal of Clinical Nutrition, 51, 72-75.

[30] Chandalia, M., Garg, A., Lutjohann, D., von Bergmann, K., Grundy, S.M. and Brinkley, L.J. (2000) Beneficial Effects of High Dietary Fiber Intake in Patients with Type 2 Diabetes Mellitus. New England Journal of Medicine, 342, $1392-$ 1398. http://dx.doi.org/10.1056/NEJM200005113421903

[31] Weickert, M.O. and Pfeiffer, A.F.H. (2008) Metabolic Effects of Dietary Fiber Consumption and Prevention of Diabetes. The Journal of Nutrition, 138, 439-442.

[32] Arvidsson-Lenner, R., Asp, N.-G., Axelsen, M., Bryngelsson, S., Haapa, E., Jarvi, A., Karlstrom, B., Raben, A., Sohlstrom, A., Thorsdottir, I., et al. (2004) Glycaemic Index. Relevance for Health, Dietary Recommendations and Food Labeling. Scandinavian Journal of Nutrition, 48, 84-94. http://dx.doi.org/10.1080/11026480410033999

[33] Wan Rosli, W.I. and Che Anis, J. (2012) The Potential of Zea mays Ears and It Extracts as an Alternative Food Nutritive Ingredients. APCBEE Procedia, 2, 141-147. http://dx.doi.org/10.1016/j.apcbee.2012.06.026

[34] Hallfrisch, J. (1990) Metabolic Effects of Dietary Fructose. The FASEB Journal, 4, 2652-2660.

[35] Crapo, P.A., Kolterman, O.G. and Olefsky, J.M. (1980) Effects of Oral Fructose in Normal, Diabetic, and Impaired Glucose Tolerance Subjects. Diabetes Care, 3, 575-581. http://dx.doi.org/10.2337/diacare.3.5.575

[36] Moore, M.C., Cherrington, A.D., Mann, S.L. and Davis, S.N. (2000) Acute Fructose Administration Decreases the Glycemic Response to an Oral Glucose Tolerance Test in Normal Adults. Journal of Clinical Endocrinology \& Metabolism, 85, 4515-4519.

[37] Heacock, P.M., Hertzler, S.R. and Wolf, B.W. (2002) Fructose Prefeeding Reduces the Glycemic Response to a High-Glycemic Index, Starchy Food in Humans. The Journal of Nutrition, 132, 2601-2604.

[38] Gentilcore, D., Chaikomin, R., Jones, K.L., Russo, A., Feinle-Bisset, C., Wishart, J.M., Rayner, C.K. and Horowitz, M. (2006) Effects of Fat on Gastric Emptying of and the Glycemic, Insulin, and Incretin Responses to a Carbohydrate Meal in Type 2 Diabetes. Journal of Clinical Endocrinology \& Metabolism, 91, 2062-2067. http://dx.doi.org/10.1210/jc.2005-2644

[39] Henry, C.J.K., Lightowler, H.J., Newens, K.J. and Pata, N. (2007) The Influence of Adding Fats of Varying Saturation on the Glycaemic Response of White Bread. International Journal of Food Sciences and Nutrition, 59, 61-69. http://dx.doi.org/10.1080/09637480701664183

[40] Wolever, T.M.S., Jenkins, D.J.A., Kalmusky, J., Giordano, C., Giudici, S., Jenkins, A.L., Thompson, L.U., Wong, G.S. and Josse, R.G. (1986) Glycemic Response to Pasta: Effect of Surface Area, Degree of Cooking, and Protein Enrichment. Diabetes Care, 9, 401-404. http://dx.doi.org/10.2337/diacare.9.4.401

[41] Bjorck, I., Granfeldt, Y., Liljeberg, H., Tovar, J. and Asp, N.G. (1994) Food Properties Affecting the Digestion and Absorption of Carbohydrates. The American Journal of Clinical Nutrition, 59, 699S-705S.

[42] Foster-Powell, K., Holt, S.H. and Brand-Miller, J.C. (2002) International Table of Glycemic Index and Glycemic Load Values. The American Journal of Clinical Nutrition, 76, 5-56. 
Scientific Research Publishing (SCIRP) is one of the largest Open Access journal publishers. It is currently publishing more than 200 open access, online, peer-reviewed journals covering a wide range of academic disciplines. SCIRP serves the worldwide academic communities and contributes to the progress and application of science with its publication.

Other selected journals from SCIRP are listed as below. Submit your manuscript to us via either submit@scirp.org or Online Submission Portal.
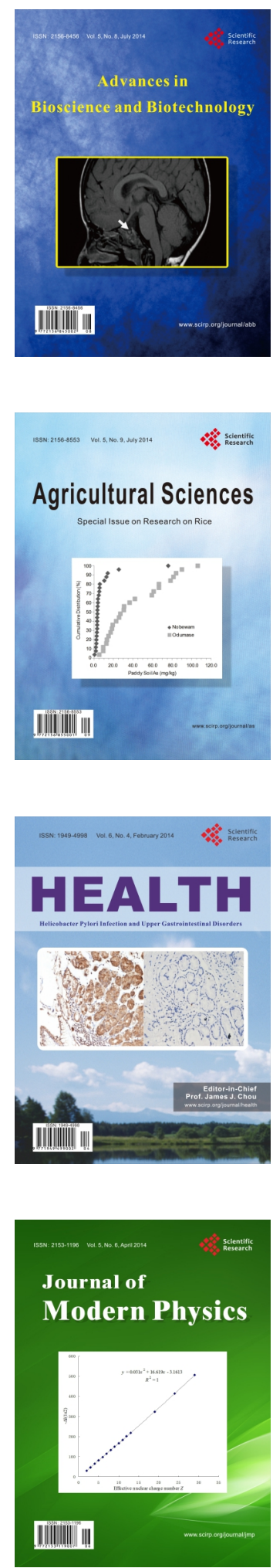
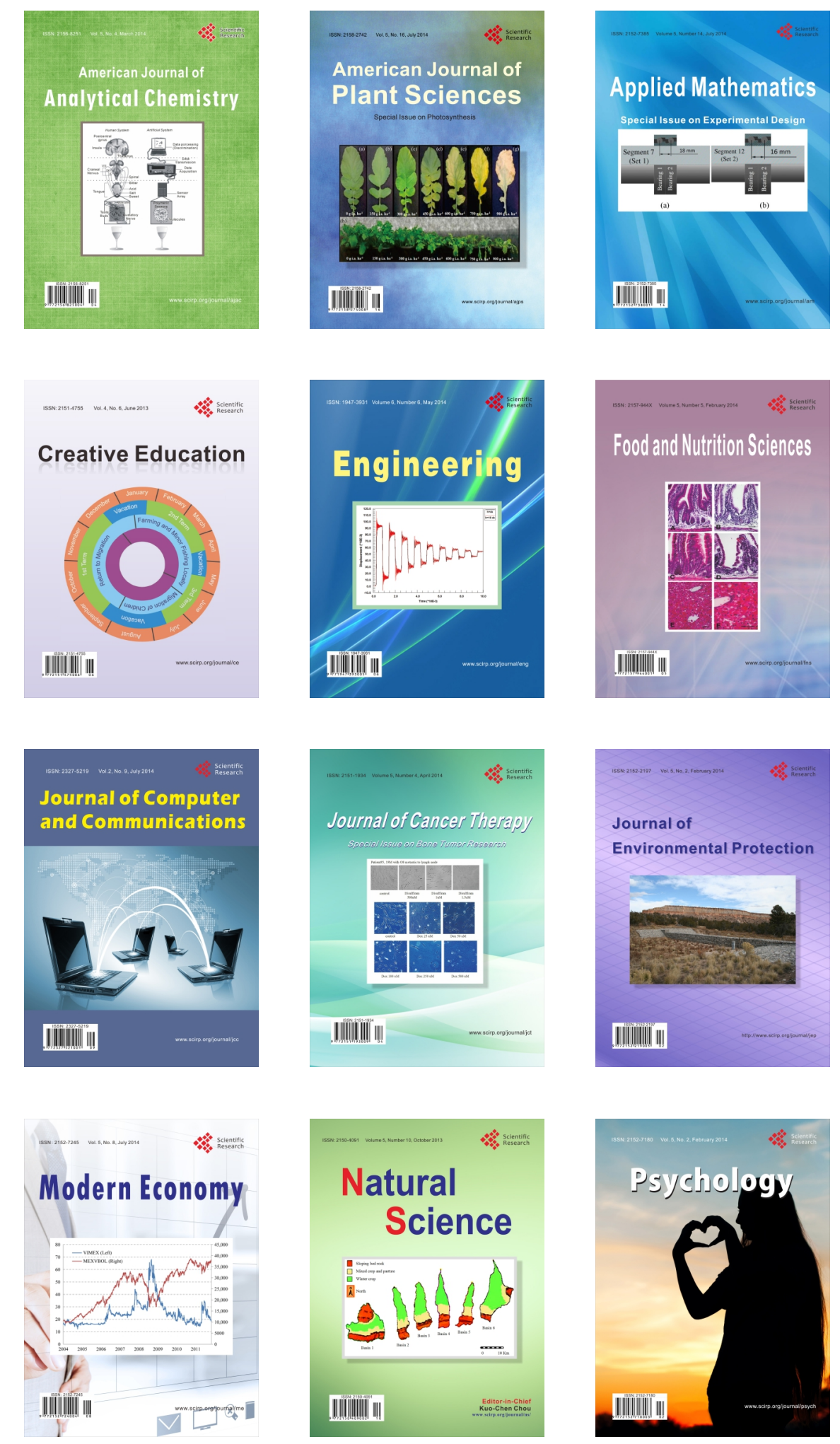